\title{
Learning Multiple Foreign Languages in Research: the Example of German (L3) after English (L2)
}

\author{
[Učení se více cizím jazykům ve výzkumu: na př́íkladu němčiny (L3) po \\ angličtině (L2)]
}

\author{
Vera Janikova
}

\section{DOI: 10.18355/XL.2015.08.02.54-71}

\begin{abstract}
Abstrakt
Procesy explicitního (intencionálního) učení se cizímu jazyku jsou v posledních desetiletích předmětem intenzivního bádání, jež je vedeno snahou těmto procesům hlouběji porozumět. Výsledky tohoto bádání poté vedou nejen $\mathrm{k}$ tvorbě teorie, $\mathrm{v}$ našem př́ípadě teorie učení se cizímu jazyku, ale zároveň poskytují pro jazykovu výuku empiricky podložená zjištění, která - při jejich reflektované aplikaci do didaktické koncepce - vedou $\mathrm{k}$ jejímu zefektivňování. Na počátku nového milénia výrazně vzrůstá požadavek moderní společnosti na znalosti více jazyků, což se stává impulsem pro razantní rozvoj výzkumu učení se více cizím jazykům (multiples Sprachenlernen, learning multiple languages), který je ukotven ve výzkumu mnohojazyčnosti a v němž se odrážejí dosavadní teorie učení se druhému cizímu jazyku, respektive modely učení se více jazykům. V článku je stručně představen vývoj tohoto výzkumu, přičemž je pozornost zaměřena především na procesy učení se druhému cizímu jazyku, kterému se jedinec učí v určitém období současně s jazykem mateřským (tzv. jazykem prvním) a prvním jazykem cizím. Př́klady vybraných studií jsou zaměřeny na konstelaci jazyků angličtina jako první cizí jazyk (L2) a němčina jako druhý cizí jazyk (L3), a to zejména proto, že těmto dvěma cizím jazykům se v současnosti učí na českých základních a středních školách největší počet žáků.

Klíčová slova

učení se více jazykům, individuální mnohojazyčnost, němčina (L3) po angličtině (L2), výzkum
\end{abstract}

\section{1. Úvod}

Explicitní či intencionální učení se cizímu jazyku je velmi složitým procesem, jenž je ovlivňován mnoha proměnnými a pro jehož objasnění existuje v současné době poměrně velké množství teorií a hypotéz (srov. např. Günther Günther, 2007). V posledních letech v souvislosti s výraznou podporou znalostí více jazyků a jejich výukou se začíná rozvíjet vedle výzkumu učení se druhému a prvnímu cizímu jazyku rovněž výzkum procesů učení se více cizím jazykům, které probíhají $\mathrm{v}$ určitém časovém úseku najednou (learning several languages simultaneously). Jedná se např́íklad o situaci, kdy žák druhého stupně základní školy s češtinou jako mateřským jazykem se několik let učí angličtině jako prvnímu cizímu jazyku a $\mathrm{v}$ šestém, sedmém či osmém ročníku se začne učit němčině jako druhému (dalšímu) cizímu jazyku. Toto bádání je v širším měřítku ukotveno ve výzkumu mnohojazyčnosti, která je fenoménem, jenž se v současné době odráží v mnoha oblastech společenského života a stává se zároveň ve zvýšené míře předmětem zkoumání řady vědních disciplín, které svými teoretickými postuláty a jejich následným empirickým ověřováním přispívají $\mathrm{k}$ hlubšímu poznání tohoto velmi různorodého fenoménu. $\mathrm{V}$ rámci této studie je mnohojazyčnost uchopena se zřetelem ke zkoumání procesů osvojování více jazyků, které nejsou doposud uspokojivě objasněny (Decke-Cornill - Köster, 2010: 9). V následující kapitole se budeme zabývat stručným nástinem vývoje výzkumu mnohojazyčnosti, všímat si budeme jak 
četnosti témat, tak stěžejních přístupů a výzkumných metod, přičemž v centru pozornosti stojí mnohojazyčnost individuální ${ }^{1}$ a paralelní učení se více (cizím) jazykům.

\section{Mnohojazyčnost ve výzkumu ${ }^{2}$ se zaměřením na učení se více jazykům}

V posledních čtyřiceti letech se v rámci výzkumu mnohojazyčnosti ve smyslu individuálního jazykového bohatství jedince postupně etablovala řada prŕstupů a metod, které se zabývají zkoumáním procesů učení se (více) jazykům. Následně představíme ty $\mathrm{z}$ nich, které jsou $\mathrm{v}$ daném výzkumném poli nejčastěji zastoupené a společně s nimi vybrané ilustrativní studie.

\subsection{Př́́stupy a výzkumné metody}

Marxová a Hufeisenová (2010: 830-831) zdůrazňují, že mnohojazyčnost v souvislosti s osvojováním jazyků patří $\mathrm{k}$ relativně novým výzkumným oblastem, v širším měřítku se stává předmětem zájmu výzkumníků až v 80. letech 20 . století (např. Thomas, 1985; Swain et al., 1990). V této době se začínají v odborné literatuře objevovat studie, které zkoumají chyby, jichž se jedinec dopouští z důvodu mezijazykového negativního transferu (interference). Brzy poté se začínají zkoumat kognitivní procesy při osvojování více jazyků (Thomas, 1985; McLaughlin, 1987), strategie učení (zejména ve vztahu L2 a L3) a vlivy již osvojených jazyků na procesy produkce $\mathrm{v}$ dalším aktuálně osvojovaném jazyce. Z výzkumných metod zde převládala metoda analýzy testů (např. Mägiste, 1984), která byla v některých studiích kombinována se zúčastněným pozorováním (Jaspert/ Lemmens, 1990) a metoda analýzy úloh zohledňujících kontrastivní přístup k osvojování jazyků (např. Apeltauer, 2001). Charakteristickým rysem tohoto výzkumu je jeho interdisciplinarita a četnost faktorů, které ovlivňují výuku jazyků zaměřenou na rozvoj funkční jazykové kompetence ve více jazycích.

1 V rámci této studie je mnohojazyčnost chápána ve dvou jejích základních kategoriích: (1) mnohojazyčnost individuální (někdy také označované jako vícejazyčnost) ve smyslu jazykového bohatství jedince a (2) mnohojazyčnosi společenská ve smyslu jazykového bohatství určité společnosti, popř. společenskopolitického seskupení (např. Kemmeter, 1993: 53; Janikova, 2013: 17). Individuální mnohojazyčnost je chápána jako schopnost jedince dorozumět se více jazyky, je v ní akcentován proces osvojování jazyků a vliv znalosti více jazyků na kognitivní vývoj jedince (Riemer, 2004: 1997). Individuální mnohojazyčnost nese prospektivní znaky, lze ji nejen uchopit a rozvíjet $\mathrm{v}$ rámci jazykového vzdělávání, ale znamená i to, že každý jedinec si ji může během svého života rozšiřovat na základě svých potřeb či zájmů. Je považována za kontinuum ve dvojím smyslu: Mění se v čase, avšak lze ji jen velmi obtížně ke konkrétnímu časovému bodu exaktně změřit (Janikova,2013: 20). ${ }^{2}$ Charakteristickým znakem výzkumu mnohojazyčnosti je interdisciplinarita, která souvisí s mnohodimenzionalitou pojmu „mnohojazyčnost“. Pro ilustraci uvádíme vybraná interdisciplinárně pojatá témata, která se objevila v posledních letech ve výzkumu společenské i individuální mnohojazyčnosti:

- mnohojazyčnost a migrace (Hu, 2003),

- mnohojazyčnost a kontaktní lingvistika (Nelde, 2003),

- mnohojazyčný lexikon (Raupach, 1994: 19-37),

- mnohojazyčnost a interference (Mertens, 2001),

- mnohojazyčnost a multikulturalita ve výuce cizích jazyků (Burwitz-Melzer, 2003) - více Janikova,2013: 91). 
V roce 2004 představuje Marxová (2004) ve své přehledové studii dosavadní směřování výzkumu mnohojazyčnosti zaměřeného na učení se cizím jazykům a jejich používání a vytvárí typologii výzkumných př́stupů a knim vázaných metod, které se v něm používají. Autorka hovoří o výzkumech (1) založených na analýze žákovských produktů, (2) zaměřených na měření výkonu, (3) zkoumajících výkon v závislosti na procesu učení (psycholingvistický výzkum), (4) sociologických a sociolingvistických a (5) orientovaných na procesy učení se druhému, popř. dalším cizím jazykům (tedy učení se více jazykům). Poslední kategorii se budeme věnovat podrobněji v kapitole 2.2.

\section{Výzkumy založené na analýze žákovských produktů}

V počáteční fázi využívá většina výzkumů voblasti mnohojazyčnosti metody analýzy chyb, která se zaměřuje na produktivní řečové dovednosti, jako je psaný a mluvený projev. Ve středu zájmu takových výzkumů stojí dle Marxové (2004) hlavně odlišnosti od jazykových norem a jejich kategorizování a analýza možných zdrojů chyb $\mathrm{v}$ důsledku interference. V posledních letech se však od př́stupu založeného pouze na analýze chyb ustupuje.

\section{Výzkumy zaměřené na měření výkonu}

Určité aspekty mnohojazyčnosti jsou dle Marxové (2004) zkoumány pomocí standardizovaného jazykového didaktického testu (např. Mägiste, 1984). Tato metoda může zkoumat jak produktivní, tak také receptivní řečové dovednosti, je úzce zaměřena na výkon a velkou roli hraje výběr vhodného testu. Tato metoda se využíá nejčastěji ke srovnávání např. bilingvních a monolingvních žáků (srov. Janik, 2012: 169-181).

\section{Výzkumy zaměřené na výkon v závislosti na procesech učení}

V kontextu zkoumání mnohojazyčnosti se nejčastěji jedná o experimentální designy výzkumů, které nejčastěji probíhají ve formě žákovských projektů. Experimentální design se zaměřuje $\mathrm{v}$ prvé řadě na interakční procesy, které probíhají během učení se cizím jazykům. Zkoumány jsou procesy osvojování mateřského jazyka a učení se prvnímu cizímu jazyku (popř. druhému jazyku) a jejich vlivy na výkon v druhém cizím jazyce (Marx, 2004; Janik, 2012: 169-181).

\section{Sociolingvisticky orientovaný výzkum}

Koncem minulého století se začíná rozvíjet výzkum opírající se o koncept jazykového a kulturního povědomí (language and intercultural awareness), jehož jádrem je koncepce interkulturního jazykového vzdělávání (Luchtenberg, 2002), a který vychází z konceptu interkulturní pedagogiky. Zahrnuje tři základní oblasti konceptualizační roviny, jimiž jsou: (1) tzv. empatie (zájem o jazyky a jejich pozitivní vnímání, které si žáci přinášejí do výuky), (2) multiperspektivita (v jazykové výuce chápané jako srovnávání jazyků v sémantickém, syntaktickém pragmatickém i textovém poli a (3) změna perspektivy (různé pohledy na konkrétní jazykové fenomény). Jazykové a kulturní povědomí je holisticky pojatým konstruktem, který se opírá o subjektivní teorie, které si jedinec v průběhu osvojování jazyků o jazycích vytváří (Knapp-Potthoff, 1997). Tento koncept zohledňuje všechny jazyky, se kterými se jedinec setkává ve svém okolí, chápe jazyk holisticky, zohledňuje kognitivní, sociální a emoční vztahy k jazykům. Učení a vyučování jazyků opírající se o koncept jazykového a kultuního povědomí vychází z fenoménu reálné mnohojazyčnosti a multikulturality školní třídy (Oomen-Welke, 1998: 287), tedy z existence více jazyků a kultur v jedné třídě. Kromě tradičních výzkumných metod (např. dotazník, didaktický test, analýza chyb) se zde využivá zejména jazyková biografie jako 
specifická metoda kvalitativního biografického výzkumu, která umožňuje získání hlubšího a komplexnějšího vhledu do jazykového a kulturního povědomí jedince. Je podobná rozhovoru, jehož cílem je sledovat životní úsek jednotlivce s důrazem na jeho jazykovou zkušenost, na učení se jazykům i jejich používání (Franceschini, 2001: 112). Počátky výzkumu s využitím jazykové biografie se datují do konce 60. a počátku 70. let dvacátého století a spadají pod nově se etablující interdisciplinární výzkumné pole naratologie. Jazyková biografie nalézá své místo nejen $\mathrm{v}$ sociolingvistickém výzkumu (např. Bock - Dumont - Groß, 2006), ale od v 90. letech dvacátého století i ve výzkumu učení a vyučování cizích jazyků. Tento výzkum využíval zpočátku deníkových zápisků, které sestavovali jedinci, kteří se učili druhému jazyku. Ty byly poté analyzovány se zřetelem k rozhodujícím vlivům na proces učení. Později byly deníky obohaceny o otevřené „memoáry“ učení se jazyku (language learning memoirs) a autobiografická interview (Franceschini/ Miecznikowski, 2004). Z hlediska procesů učení se více jazykům se objevují jazykové biografie doposud nejčastěji ve smyslu reflexe vlastního učení prováděné zpravidla $\mathrm{v}$ rámci akčního výzkumu s cílem tento proces zefektivnit. Zkoumání jsou podrobovány jazykové jevy i strategie učení, využívána je metoda reflektivního deníku a následného rozhovoru mezi žákem a učitelem (Caesar, 2009) ${ }^{1}$.

Tyto počáteční výzkumy přinesly mj. následující závěry (srov. Apeltauer, 2001: 636):

- Multilingvní a bilingvní jedinci se učí dalšímu jazyku mnohem uvědoměleji a promyšleněji než jedinci monolingvní.

- Multilingvní jedinci jsou schopni vyššího stupně abstrakce a rozpoznávání jazykových vzorů (struktur), jsou schopni flexibilněji vypracovávat úlohy a využívat pamětové strategie.

- Již osvojené jazyky mají pozitivní vliv na učení se dalšímu jazyku především tehdy, jestliže patří do jedné jazykové rodiny.

- V oblasti receptivních řečových dovedností se ukazuje vliv prvního (mateřského) jazyka na další jazyky zásadnější, než již osvojených jazyků dalších (Möhle, 1989).

${ }^{1}$ Jako sociologický fenomén je vnímán $\mathrm{v}$ řadě výzkumů postoj $\mathrm{k}$ mnohojazyčnosti z perspektivy jedinců, kteří jsou mluvčími jiného mateřského jazyka, než je $v$ dané společnosti jazyk úřední. V Německu hraje v posledních deseti letech významnou roli (zejména v germanistické lingvistice) výzkum v oblasti jazyků migrantů (např. Meng, 2001). Objevují se také výzkumy, které se zaměřují na otázky identity spojené s jazykem (např̀. Androutspoulos, 2006). I zde je pro získání jazykových biografií nejčastěji využívána metoda narativního rozhovoru (např. Tophinke, 2002). Využíváno bývá rovněž "zpráv" (osobních výpovědí) k postojům a zkušenostem $\mathrm{s}$ mnohojazyčností v Německu, $\mathrm{k}$ čemuž bývá $\mathrm{k}$ vyhodnocení dat využívána analýza rozhovoru. Podobně, avšak s větším důrazem kladeným na sociolingvistická východiska, zaměřuje svůj výzkum Selting se svými spolupracovníky (Selting, 2009). Tito výzkumníci analyzovali z lingvistického hlediska transkribovaný korpus, který získali pomocí 14 narativních interview v celkovém rozsahu cca 22 hodin, prričemž respondenty byli bilingvní jedinci (Vietnamci) žijící v Německu. Výsledky mimo jiné poukázaly na význam osobnostních charakteristik a způsobu vyjadřování podmíněného vlivem sounáležitosti se vzory vietnamské kultury (např. často se objevuje zdrženlivost ve výrocích vyjadřovaná neosobním tvarem man, stejně jako v těch místech, která respondenti vnímali jako sebechválu nebo kritický výrok). (srov. Janikova, 2013: 99) 
- Osvojení psané podoby různých jazyků se ukazuje jako facilitující aspekt při učení se třetímu a dalším jazykům (srov. také Swain et al., 1990).

\subsection{Výzkumy orientované na procesy učení se druhému, popř. dalším cizím jazykům}

Jednou z výzkumných oblastí je intencionální učení se více jazykům v rámci jazykového vzdělávání, což je provázeno snahami o nalézání odpovědí na otázky spojené s hledáním rozdílů mezi učením se prvnímu a druhému cizímu jazyku, př́íp. jazykům dalším. Toto hledání je podložené analýzou stávajících teorií a hypotéz ř́zeného i neřízeného učení se jazykům, které se do nedávné doby zaměřovalo odděleně na jazyk mateřský, druhý a první cizí a tvorbou nových teorií, které objasňují procesy učení se více jazykům ${ }^{1}$.

Při zkoumání procesů učení se druhému cizímu jazyku ve školním prostředí je třeba vzít v úvahu řadu aspektů, které jsou pro ně signifikantní. Jsou to především charakteristiky samotných žáků, kteři si do výuky přinášejí znalosti prvního cizího jazyka (popř. dvou či více cizích jazyků), stejně jako znalosti sociokulturní se zřetelem ke kultuře vlastní i kulturám jiným. Tito žáci:

- jsou starší a kognitivně zralejší. Z toho vyplývá, že jsou schopni kognitivně zpracovávat komplexnější a abstraktnější obsahy, postupují při svém učení systematičtěji a rychleji (Hufeisen - Marx, 2001: 5). S tím souvisí i to, že žáci vědoměji používají učební strategie, ví, nebo alespoň tuší, co jim při učení se jazykům pomáhá.

- již ovládají základní lingvistickou terminologii nejen v mateřštině, ale v prvním cizím jazyce, což vytváři bázi nejen pro srovnávání více jazykových systémů, identifikování shod, podobností a rozdílů a tím pro rozvoj jazykového povědomí. Ve svém faktorovém modelu hovoří Hufeisenová (2003) o tom, že právě tato

${ }^{1}$ Od 90. let dvacátého století dochází k přehodnocení názoru, že osvojování každého dalšího cizího jazyka se neliší od osvojování prvního cizího jazyka a pomocí výzkumů bylo zjištěno, že existují kvalitativní i kvantitativní rozdíly mezi učením se prvnímu a druhému cizímu jazyku. Výsledky analýz těchto rozdílů umožnily vytvořit několik modelů pro učení se více cizím jazykům. Tyto modely je třeba vnímat jako pokusy o vysvětlení procesů osvojování více jazyků, které na základě výsledků prvních empirických šetření překonaly dosavadní teorie a hypotézy o osvojování jazyků, jež byly a priori zaměřeny pouze na osvojování prvního (mateřského) a druhého (popř. prvního cizího) jazyka. Doposud však pro jejich verifikaci, popř. falzifikaci neexistuje dostatečné množství dokladů, které jsou zásadní pro další vývoj $\mathrm{v}$ oblasti tvorby teorie (Hufeisen, 2003: 3). Jednotlivé modely akcentují různá východiska a zorné úhly pohledu na danou problematiku, jsou rozpracovány v odlišné šíři a hloubce. Patř́i k nim (1) dynamický model mnohojazyčnosti (DMM - Dynamic Model of Multilingualism; Jessner, 1997; Herdina - Jessner, 2002); (2) funkční model roli (RFM - Rollen-Funktions-Modell/ Language Switches Model, Hammarberg, 2001); (3) model osvojováni cizich jazyků (FLAM - Foreign Language Acquisition Model, Groseva, 1998); (4) ekologický model (EMM - Ecological Model of Multilinguality; Aronin - O Laoire, 2001) a (5) faktorový model (Factor Model/ Faktorenmodell, (Hufeisen, 2003). Tyto modely jsou doposud vnímány ve smyslu pokusu o vysvětlení určitého fenoménu, kterým je osvojování více jazyků. Překonaly sice na základě doposud získaných empirických dat status hypotézy, pro verifikaci, popř. falzifikaci však vyžadují ještě další empirická šetření a teoretické ukotvení (srov. Janikova, 2013: 37-40; Janikova, 2014). 
situace patří k signifikantním specifikám učení se druhému cizímu jazyku, nebot' žáci mohou navázat na již vytvořenou lingvistickou bázi, a to mateřského i prvního cizího jazyka. $\mathrm{Z}$ hlediska teorie učení tento proces rezonuje $\mathrm{s}$ kognitivistickým a konstruktivistickým pojetím.

- již získali zkušenosti s učením se jednomu cizímu jazyku a navíc se jim dostalo již několikaleté výuky mateřského jazyka, a stali se tak již vnímavější k jazykovým strukturám i zvláštnostem celého jazykového systému mateřštiny. AbendrothTimmerová a Breidbach (2000: 14) dokládají, že žáci jsou ve druhém cizím jazyce rovněž schopni lépe využívat pozitivního transferu.

- jsou při učení se druhému cizímu jazyku zpravidla motivováni jinak, než je tomu u prvního cizího jazyka. Výzkumné studie poukazují na řadu subjektivních i objektivních faktorů, které tuto motivaci ovlivňují (např. Lindemann, 2007). Ve smyslu negativní motivace je nejčastěji zmiňováno - zvláště u žáků na základních školách - přesvědčení, že stačí jeden cizí jazyk, zejména tehdy, pokud je prvním cizím jazykem angličtina (např. Janíková, 2013b), nebo negativní zkušenosti s výukou prvního cizího jazyka či se (zdánlivě) malým pokrokem v rozvoji schopnosti komunikovat $\mathrm{v}$ druhém cizím jazyce a/nebo s obtížemi s „novou“ gramatikou a slovní zásobou, což vede k frustraci a tím i snížení jak vnitřní, tak i vnější motivace (Lindemann, 2007).

- mívají z hlediska konkrétního učiva při učení se druhému cizímu jazyku obtíže zejména v oblasti výslovnosti, což je způsobené postupnou ztrátou schopnosti osvojit si bezchybnou výslovnost tak, jak se to daří v nižším věku; fyziologicky je tento jev dán snížením cerebrální plasticity (Grotjahn, 1998: 48).

- jsou již mnohem lépe schopni vnímat interkulturní dimenzi spojenou s učením se jazykům, citlivěji vnímat nejen jazykovou ale i kulturní rozmanitost, a to nejen na základě předchozí jazykové výuky, ale i větších osobních zkušeností (Neuner Hufeisen et al., 2009: 37-39, Janikova 2013b: 77-78).

Výzkum procesů učení se více cizím jazykům se zabývá všemi aspekty, které jsou pro tyto procesy charakteristické, z různých zorných úhlů a se zapojením celé řady vědních disciplín. Patří mezi ně - stejně jako ve výzkumu učení se prvnímu cizímu jazyku - oborová lingvistika (např. germanistika, anglistika, rusistika aj.), psycholingvistika, pragmalingvistika, textová lingvistika, sociolingvistika, neurolingvistika, teorie osvojování jazyků, vývojová psychologie či pedagogika. Následně uvádíme vybrané př́klady oblastí a témat, jež se v první fázi tohoto výzkumu nejčastěji objevují.

Jak uvádí Pilypaityté (2013: 25), je z hlediska lingvistiky nejčastěji zkoumán transfer mezi jednotlivými jazyky, tedy přenos jazykových struktur mateřského a/nebo dalšího osvojeného jazyka (popř. dalších cizích jazyků) do jazyka právě osvojovaného. První zkoumanou oblast transferu mezi prvním a druhým cizím jazykem se stala inference. Př́i analýze řečové produkce ve druhém cizím jazyce totiž bylo zjištěno, že - oproti tvrzení kontrastivní hypotézy - nesla výraznější znaky prvního cizího jazyka než znaky jazyka mateřského. V rámci transferu se počáteční studie zabývaly především interferencí, tedy transferem negativním (např. Stedje, 1976; Hufeisen,1993; Vogel, 1992).

Z hledika psycholingvistiky jsou v kontextu výzkumu učení se druhému cizímu jazyku zkoumány fenomény jako vícejazyčný mentální lexikon (např. Cenoz/ Hufeisen/ Jessner, 2003), který zkoumá zejména způsob, jak se ukládají slova více jazyků v paměti, jak se slova jednoho jazyka propojují se slovy jiného jazyka a jak na sebe vzájemně reagují. Zkoumána je rovněž oblast metalingvistického povědomí u vícejazyčných jedinců (např. Jessner, 2000). Vliv tradice učení a konkrétního kontextu, v němž procesy učení se více cizím jazykům probíhají, zkoumají např. 
Kärchner-Oberová (2009). Řada výzkumných prací přistupuje ke zkoumané problematice z pohledu psychologie učení, přičemž poměrně hojně je zde zastoupena oblast strategií, které vícejazyční jedinci uplatňují při učení se více jazykům, při jejich recepci a produkci (např. Mißler, 1999) (srov. Pilypaityte, 2013: 25).

Různým tématům odpovídají i různé výzkumné metody, nejčastěji se k výzkumu orientovaného na proces učení se druhému, popř. dalším jazykům využívají dle Marxové (2004) dotazníkové metody, interview, introspektivní metody jako je např. myšlení nahlas nebo analýza diskursu (Rehbein, 2001; Widdowson, 2007), která je mj. využívána při zkoumání toho, do jaké míry a jakým zpưsobem se vícejazyčný mluvčí při komunikaci přizpůsobuje použitému jazyku partnera, jenž sám také ovládá. V lingvisticky zaměřených šetřeních orientujících se na zjišt'ování mezijazykového transferu bylo využíváno zejména metody analýzy chyb, přičemž byly zkoumány odchylky od jazykové normy $\mathrm{v}$ psaných a mluvených projevech ve druhém (cílovém) jazyce, které byly poté klasifikovány se zohledněním dřive naučených či osvojených jazyků. Tak bylo možné doložit vliv prvního cizího jazyka na druhý, popř. další cizí jazyk (např. Hufeisen, 1991; Dentler, 1998; Groseva, 1998, Pilypaityte, 2013: 26). V psycholingvisticky orientovaném výzkumu učení se více cizím jazykům jsou užívány následující metody: slovní asociace, myšlení nahlas, testy k rozlišení lexikálního významu, doplňování slov či překlad.

Charakteristickým znakem těchto výzkumů je, že - na rozdíl od výzkumů dřívějších, které většinou zkoumají pouze výskyt určitých jevů - zde stojí v popředí otázky, v jaké podobě a proč se tyto jevy v recepci i produkci vícejazyčných jedinců objevují. Transfer začíná být ve větší míře vnímán jako fenomén facilitující proces učení se více jazykům, zkoumání zaměřené na interferenci ustupuje do pozadí a pozornost je věnována spíše transferu pozitivnímu.

\subsubsection{Vybrané ilustrativní studie}

V této kapitole jsou exemplárně představeny vybrané výzkumy zabývající se procesy učení se více jazykům, které - v rámci možností časopisecké studie poskytují náhled na různorodost témat a metodických př́stupů ${ }^{1}$ tohoto typu výzkumu. Nejdřive jsou uvedeny studie, v nichž je proces učení se více cizím jazykům zkoumán $\mathrm{v}$ různé jazykové konstelaci, a poté několik studií v jazykové konstelaci němčina jako druhý cizí jazyk (L3) po angličtině jako prvním cizím jazyce (L2).

Jak bylo uvedeno výše, do popředí zájmu výzkumu učení se více jazykům se dostává transfer, resp. pozitivní mezijazykový transfer. Transfer v oblasti tvorby psaného textu ve více jazycích zkoumali např. Cenozová a Gorter (2011: 361), kteří ve své studii analyzovali texty 165 baskických žáků, jejichž mateřským jazykem byla baskičtina nebo španělština. Baskičtina byla rovněž vyučovacím jazykem, španělština a angličtina jsou předměty ve školním vzdělávacím programu, přičemž španělština vykazuje status spíše druhého jazyka, angličtina je jazykem cizím. V rámci výzkumu sestavovali respondenti na základě obrazového podnětu psaný text ve třech jazycích (obrázkový príběh nebo popis obrázku). Tyto texty byly následně analyzovány. Kritérii byly obsah, organizace textu, gramatika a slovní zásoba a u výsledků mezi třemi dvojicemi jazykových mutací textů byla zjišt'ována statisticky signifikantní

1 Pro získání hlubšího vhledu do zkoumané problematiky slouží rozsáhlejší přehledové studie (např. Hufeisen, 1993; Apeltauer, 2001), četné odborné stati (např. Marx - Hufeisen, 2010) nebo odborné knihy prezentující jednotlivá výzkumná šetření (např. Riehl, 2004; Wolff, 2006; Cavallini, 2010; Muller - Kupisch et al., 2011). 
korelace. Kvalitativní textově lingvistická analýza poskytla empiricky podložený závěr, že při produkci psaného textu probíhá vícesměrný transfer vykazující proaktivní charakter. Dochází $\mathrm{k}$ němu nejen $\mathrm{v}$ rámci určitého jazyka, ale i mezi různými jazyky a stává se významným prvkem facilitujícím učení (Cenoz/Gorter, 2011: 360).

Kobayashi a Rinnert (2013) zkoumali v longitudinální studii (délka trvání sběru dat 2,5 roku) psané texty (argumentativní esej) jedné japonské dívky v jejím mateřském jazyce (japonština) a $\mathrm{v}$ jejích cizích jazycích (angličtina a čínština). Ve studii byla mj. zohledňována aktuální úroveň znalostí všech těchto jazyků a schopnosti je použivat. Výsledky následně provedené textově lingvistické analýzy ukazují, že jednotlivé jazykové jevy se pro vyjádření konkrétního obsahu $\mathrm{v}$ jednotlivých jazycích liší, na úrovni makrostruktury textu byla identifi kována shoda ve všech jazykových mutacích textu. Autoři studie mj. zjistili, že respondentka transferovala své znalosti o struktuře textu $\mathrm{z}$ japonštiny a angličtiny do textu napsaného v čínštině (Kobayashi - Rinnert, 2013: 17).

De Angelis a Jessnerová (2012) zkoumali tzv. jazykové interakce mezi texty psanými $\mathrm{v}$ italštině jako mateřském jazyce, němčině jako prvním cizím jazyce a angličtině jako druhém cizím jazyce. Tyto texty vytvořili žáci 8 . ročníku základní školy v Jižním Tyrolsku. Autoři se při analýze textového korpusu zaměřili na jeho koherenci a kohezi, kterou měřili na základě v textu identifikovaného počtu slov nebo vět (t-units) (de Angelis - Jessner 2012: 53). I tento výzkum ukázal vícesměrné působení negativního i pozitivního transferu. Mimo jiné bylo zjištěno, že v řadě prŕpadů působí mateřský jazyk (italština) pozitivněji na druhý cizí jazyk (angličtina) než na první cizí jazyk (němčina).

Bär (2009) provedl longitudinální studii kvalitativního charakteru $\mathrm{k}$ tématu učení se více jazykům, které patří do jedné jazykové rodiny, v němž si stanovil za cíl, že typ výuky, který implementuje koncept didaktiky meziporozumění ${ }^{1}$, již po prvních několika vyučovacích hodinách činí žáka schopným na elementární úrovni novému cizímu jazyku rozumět. Výzkum zahrnuje čtyři př́ípadové studie (případem zde byla skupina žáků), které byly realizovány v průběhu dvou let se čtyřmi skupinami žáků se znalostmi různých jazyků románské jazykové rodiny, kteří se učili dalšímu jazyku patřícímu do této rodiny. Ve dvou studiích se jednalo o učení se španělštině, ve druhých dvou o učení se italštině. Autor volí metodu akčního výzkumu

1 Didaktika meziporozumění nebo také interkomprehenze (lat. inter „mezi“, komprehension „porozumění“; angl. didactics of intercomprehension; něm. Interkomprehensiondidaktik). Interkomprehenze je v př́mém souladu s mentálním zpracováním jazyků tak, jak se to děje při porozumění jazykovým informacím. Spočívá ve spontánní nebo uvědomělé identifikaci jazykových schémat, v propojení nových jazykových vzorů (slov či gramatických struktur) s již získanými znalostmi o jazycích, což ovlivňuje konstrukci schémat nových. Zvlášt' zrretelně se to odráží ve vícejazyčném mentálním lexikonu. Na základě cíleného využití interkomprehenze může docházet k rychlému pokroku při učení se jazykům. Materiálním předpokladem je dostatečná existence tzv. bází transferu, kterými rozumíme podobnosti a analogie mezi známými schématy a novými znalostmi (např. něm. Haus - angl. house). Zatímco mezi jazyky jedné jazykové rodiny je těchto podobností možné nalézt relativně mnoho, mezi jazyky rozdílných jazykových rodin nejsou zastoupeny zpravidla vůbec (např. čeština a čínština) (srov. Janikova, 2013: 69).

61

XLinguae Journal, Volume 8 Issue 2, April 2015, ISSN 1337-8384 
a postupy kvalitativního výzkumu, přičemž výzkumníka s jeho subjektivitou vnímá jako nedílnou součást procesů výzkumu, která musí být explicitně zdůrazněna. Tento předpoklad je u něho splněn tím, že autor výuku nejen pozoruje, ale i sám vede. Ke sběru dat byly využity videonahrávky výuky, audionahrávky protokolů (hlasitého přemýšlení), žákovské práce, didaktické texty, deníky žákủ a interview s žáky. Další data byla získána pomocí přímé zpětné vazby od kolegů učitelů, u nichž bylo navíc provedeno i dotazníkové šetření. Zapojení žáků a učitelů mělo za cíl dosažení reflektované subjektivity dat. První skupinou respondentů bylo 28 žáků osmého ročníku gymnázia v Sársku (Saarland), jejichž jazyková výuka byla po dobu tří týdnů vedena podle principů didaktiky meziporozumění. Druhou skupinu respondentů tvořilo 25 žáků desátého ročníku gymnázia v Hesensku (Hessen), kteří se na počátku školního roku 2005 účastnili čtyřdenní projektové výuky. Třetí skupinou bylo 21 studentů devátého ročníku bilingvního německo-francouzského gymnázia (rovněž v Sársku), u nichž byl výzkum prováděn v souvislsoti $\mathrm{s}$ účastí na projektovém týdnu rovněž v roce 2005; u poloviny z nich byla francouzština druhým jazykem. Čtvrtou skupinu tvořilo 15 studentů, kteří navštěvovali bud’to 8 . nebo 9. ročník gymnázia, také v Sársku, u nichž byla po dobu čtyř dnů realizována projektová výuka. Cílovým jazykem první a druhé skupiny byla španělština, třetí a čtvrté italština. Žáci si do doby výzkumného šetření osvojili v průměru dva další jazyky, část žáků se učila francouzštině již od třetí třídy. Hlavní výzkumná otázka zněla: Jak rozumi žáci gymnázia slovům, větám a textům jazyka, kterému se formálně neučili, ale který patř́ kjazykům, jež jsou príbuzné těm, které již ovládaji? Výzkumník, který působil zároveň jako vyuučují, respondenty motivoval $\mathrm{k}$ učení se dalšímu románskému jazyku, ve společné diskusi s nimi poukazoval na řadu jevů, které jsou těmto jazykům společné, a pokytoval jim př́ležitost, aby sami objevovali shody a rozdíly v oblasti sémantiky, hláskoví a syntaxe při srovnávání jednotlivých zúčastněných jazyků.

Výsledky ukázaly mj. to, že sami studenti byli překvapeni, jak rychlý a velký pokrok udělali v oblasti schopnosti porozumění a jednoznačně se vyjadřovali k tomu, že osvojení určitých strategií jim tento proces významně usnadnilo. Stejně tak - dle jejich výpovědí - $\mathrm{k}$ tomu přispělo uvědomování si jazykových paralel. Jako přemost'ovací jazyk jim sloužila zejména francouzština, ale využívali i němčinu, angličtinu, španělštinu či latinu - v závislosti na jazykové biografii konkrétního jedince (srov. Janíková, 2013b).

\section{Výzkum v oblasti učení se dvěma cizím jazykům v konstelaci němčina (L3) po angličtině (L2)}

V oblasti výzkumu zaměřujícího se na procesy učení a vyučování němčině po angličtině nacházíme řadu teoretických a empirických studií především v zahraničí (např. Meissner - Reinfried, 1998; Hufeisen - Marx, 2001; Hufeisen - Neuner, 2005; Neuner, 1996; 2003; Rampillon, 2003 aj.). Již v roce 1998 mapuje Hufeisenová stav výzkumu této problematiky v souvislosti s tvorbou modelů osvojování si více jazyků a metodami pro výuku dalšího cizího jazyka. V roce 2004 ve své studii poté stejná autorka tematizuje otázky spojené s efektivním využíváním zkušeností pro učení se němčině jako druhému cizímu jazyku po angličtině, které žáci získali při učení se angličtině jako prvnímu cizímu jazyku. Vliv angličtiny jako prvního cizího jazyka (L2) na učení se němčině jako druhému cizímu jazyku (L3) je zkoumán i v mimoněmeckém kontextu. Za zmínku stojí např́íklad Polsko (Targonska, 2004), Bulharsko (Groseva, 1998), Řecko (Spiropoulou, 2000) nebo Švédsko (Kjär, 2000), v českém prostředí se výzkumu mnohojazyčnosti sohledem na tuto jazykovou konstelaci věnují např. Janíková (2013a) nebo Sorger, Káňa, Janíková, Reitbrecht, Brychová (2013). Následující vybrané studie nabízejí podrobnější pohled na tuto výzkumnou oblast. 
Dentlerová (1998) se snažila na základě analýzy korpusu vytvořit typologii chyb v produkci druhého cizího jazyka, kterým byla němčina; prvním jazykem byla švédština a druhým angličtina. Analyzovaný korpus tvořily psané texty na téma „,v̌ední den“ („Alltag“). L1 představoval švédský jazyk, L2 anglický jazyk a L3 německý jazyk. Respondenty byli žáci ve věku od 16 do 18 let, kontrolní skupinu tvořila skupina dospělých kolem 30 let. Výsledky analýzy ukázaly, že nejvíce zastoupenými typy chyb byly výpůjčky (přejímání slov z jiného jazyka, „borrowings“ a tzv. zrádná slova“"(false friends).

Lindemannová (2007) se zaměřila na zkoumání motivace norských žáků pro učení se němčině jako druhému cizímu jazyku po angličtině. Výzkumným vzorkem byli žáci učící se němčině jako volitelnému předmětu v druhém pololetí 7. ročníku (poslední rok základní školy) a $\mathrm{v} 8$. ročníku, který je prvním ročníkem tříletého následujícího stupně povinného školního vzdělávání ${ }^{1}$. Jedním z impulsů pro tento longitudinální výzkum trvající jeden a půl roku se stala pozorovatelná tendence poklesu zájmu žáků o volbu němčiny jako druhého cizího jazyka (mnohdy ve prospěch španělštiny, pro kterou však v prvních letech nového tisíciletí chyběl odpovídající počet kvalifikovaných učitelů) i fakt, že poměrně významný počet žáků brzy tuto výuku opustil a zvolil si jiný předmět. Hlavní výzkumné otázky zněly: Jaká je motivace žáků ve výuce němčiny? Čim lze vysvětlit vysoké počty žákü, kteři předčasně ukonči učeni se němčině? Které faktory motivace mohou přispět ke zvýšení zájmu o výuku němčiny? Metodami sběru dat byl dotazník a skupinové i individuální interview s žáky a interview s učiteli němčiny. Longitudinální studie sleduje nejen zjištění status quo motivace $\mathrm{k}$ učení se němčině, ale umožňuje zkoumat $\mathrm{i}$ její vývoj. Výzkumný vzorek tvořilo 10 žáků, kteří byli výzkumnicí sledováni po dobu jednoho a půl roku. Výsledky ukazují, že velký vliv na motivaci žáků učících se němčině a jejich úspěch mají zejména rámcové podmínky, které se př́mo netýkají výuky, jako nejvýznamnější byla identifikována nesprávná doporučení pro volbu tohoto předmětu ze strany nejbližšího okolí žáků. Vlastní výuka i kompetence učitelů němčiny byly většinou respondentů hodnoceny kladně, avšak demotivačně zde působí status předmětu jako volitelného, kterému nevěnují tolik pozornosti a úsilí, jako předmětům povinným. Pro úspěšné řešení dané situace se ukazuje důležitým motivovat žáky již v období před volbou druhého cizího jazyka (v tomto případě němčiny) a poté musí následovat kontinuální učení $\mathrm{s}$ jasně definovanými cíli.

Motivací při učení se více jazykům v jazykové konstelaci angličtina jako první cizí jazyk a němčina jako druhý cizí jazyk) se ve své studii zabývala Janíková (2013a), která zkoumala, jak jsou motivováni žáci v českých základních školách a studenti čtyřletých a osmiletých gymnázií při učení se němčině jako druhému cizímu jazyku $(\mathrm{n}=325)$, přičemž byla zkoumána motivace $\mathrm{z}$ perspektivy žáka (extrinsistická a intristická) i učitele (motivování). Ke sběru dat bylo využito dotazníkové metody (dle Solmecke, 1993). Výsledky výzkumného šetření ukázaly, že mladší žáci jsou motivování spíše emocionálním prožitkem, starší žáci (studenti gymnázií) přistupují k učení se druhému jazyku více pragmaticky a s uvědomováním si důležitosti jazykových znalostí pro svůj budoucí osobní i profesní život. Informace získané při podrobnější analýze získaných dat nabízejí řadu podnětných impulzů pro metodicko-didaktické koncepty výuky druhého cizího jazyka. Za všechny zmiňujeme:

\footnotetext{
${ }^{1} \mathrm{Na}$ norských školách je angličtina povinným prvním cizím jazykem od prvního ročníku základní školy (tzv. barneskole, 1.-7. ročník). Žáci si mohou zvolit i další cizí jazyk. Tuto volbu mají i v další fázi povinné školní docházky (8.-10. ročník, tzv. ungdomsskole).
} 
cílené zohledňování afektivní dimenze výuky zejména u nižších věkových skupin žáků a zabudovávání obsahů i výběru výukových metod zaměřených na osvojování cizího jazyka pro profesní účely.

\subsection{Transfer ve výzkumu produkce psaného textu v kontextu učení se více jazykům (na př́íkladu němčina po angličtině)}

Jak bylo uvedeno výše, stojí jazykový transfer v popředí zájmu počátečního - především lingvisticky orientovaného - výzkumu učení se cizím jazykům, přičemž byla pozornost zaměřena na transfer negativní, tedy interferenci. Teprve v posledních letech se do popředí zájmu dostává transfer pozitivní, zvláště pak ve výzkumu učení se více jazykům, a to zejména $\mathrm{v}$ oblasti řečové produkce, prričemž jednoznačně převládá výzkum v oblasti mluvního projevu, výzkumná šetření v oblasti psaní ve více jazycích se i v zahraničí objevují doposud marginálně (Pilypaityte, 2013: 23-37), $\mathrm{v}$ českém prostředí bylo provedeno pouze jedno výzkumné šetření tohoto zaměření (Sorger - Kana et al., 2013). Následně vybíráme exemplárně dvě studie, které byly realizovány v zahraničí (Itálie a Chorvatsko) a podrobněji představíme výše zmíněné šetření provedené v České republice.

Cavalliniová (2010) zkoumala vliv negativního i pozitivního transferu při psané produkci textů u italských žáků, jejichž mateřským jazykem je italština, prvním cizím jazykem angličtina a druhým cizím jazykem němčina. Pomocí kvalitativní, textově lingvistické analýzy psaných žákovských textů (slohové práce k tématu 'moje město', 'volný čas v mém městě' a 'moje ideální dovolená'), které byly sestaveny žáky různého věku a různé jazykové úrovně (někteří respondenti se učí němčině jako třetímu cizímu jazyku L4) na dvou italských gymnáziích a jedné střední škole ve švýcarském kantonu Tessin, byly zjišstovány pozitivní i negativní vlivy angličtiny jako prvního cizího jazyka na němčinu jako druhý cizí jazyk, přičemž byl zohledňován i vliv italštiny jako mateřského jazyka na další jazyky. Pozitivní transfer byl identifi kován zejména v oblasti syntaxe (postavení adjektiv) a lexika.

Horvatić Čajko (2013: 52-68) ve své studii představuje výsledky svého hledání odpovědí na otázku, jak se odrážejí již získané jazykové znalosti (chorvatština a angličtina) při učení se němčině jako druhému cizímu jazyku v oblasti produkce psaného projevu a jak se přitom projevuje působení mezijazykového transferu. Korpus analyzovaných textů tvoří e-maily, které psali15letí začátečníci ve výuce němčiny jako cizího jazyka jako reakci na určitý podnět

(taktéž e-mail), a to $\mathrm{v}$ testové situaci. Jedná se o žáky se znalostí chorvatštiny jako mateřského

jazyka (L1) a angličtiny jako prvního cizího jazyka (L2), kteří se v té době 10 měsíců učili němčině jako druhému cizímu jazyku (L3). Kvalitativní analýza se zaměřuje na fonologickou, morfologickou, lexikální a syntaktickou rovinu jazyka a kulturně specifické komunikační vzorce. Získané výsledky ukazují, že žáci nejenže transferovali do němčiny prvky z typologicky blízké angličtiny, ale i ze své relativně vzdálené slovanské mateřštiny (chorvatština). Transfer $\mathrm{z}$ chorvatštiny se ukázal dominantnějším v morfologické a syntaktické rovině, naproti tomu se vliv angličtiny projevil zejména $\mathrm{v}$ lexikální rovině. $\mathrm{V}$ sestavených textech se objevily různé mezijazyky jako jevy podmíněné mezijazykovým transferem, což autorka nevnímá jako nežádoucí deficit $\mathrm{v}$ jazykové produkci, ale jako prrirozenou vlastnost procesu osvojování jazyků. Při cíleném a konstruktivním uchopení těchto jevů v jazykové výuce dochází k rozvoji jazykového povědomí a efektivnějšímu učení se jazykům, což je v souladu se zásadami didaktiky mnohojazyčnosti. 
I v České republice se angličtina ${ }^{1}$ stává prvním cizím jazykem, kterému se většinou začínají učit žáci ve třetím ročníku základní školy a jiné cizí jazyky zaujímají pozici dalšího cizího jazyka. Podobně jako v řadě jiných zemí, se tak i v českém vzdělávacím systému stává němčina typickým druhým cizím jazykem (srov. Sladkovská, 2010). K posílení její výuky pozice přispělo, že od školního roku 2013/2014 byl v Rámcovém vzdělávacím programu pro základní vzdělávání (RVP ZV, 2013) Další cizí jazyk na 2. stupni základních škol přeřazen z Doplňujících vzdělávacích oborů do oblasti Jazyk a jazyková komunikace. To znamená, že další jazykovou výuku budou nejpozději od 8. ročníku absolvovat všichni žáci, at’ se jedná o Další cizí jazyk nebo v odůvodněných případech o rozvíjení Cizího jazyka (tj. prvního cizího jazyka, kterým je zpravidla angličtina) (Janíková, 2013b: 30). Tento fakt se začíná odrážet i v českém výzkumu učení a vyučování cizích jazyků, přičemž je třeba zdůraznit fakt, že zde výzkum zaměřený na zkoumání jazykového transferu ve smyslu zjišt'ování míry vzájemného ovlivňování více disponibilních jazyků (mateřského, prvního a druhého cizího jazyka) v produkci psaného textu nebyl doposud realizován. Prvním významnějším pokusem o uchopení tohoto tématu je výzkumné šetření realizované v rámci projektu „, Mnohojazyčnost v české škole: učení a vyučování němčiny po angličtině (P407/11/0321). Působení jazykového transferu zde bylo zkoumáno $\mathrm{v}$ rámci produkce souvislého psaného textu v několika jazycích. Výzkumný projekt sleduje otázku, zda texty respondentů (žáků vyšších tříd ZŠ a nižších tříd osmiletých gymnázií) psané v češtině jako mateřském jazyce, angličtině jako prvním cizím jazyce a němčině jako druhém cizím jazyce vykazují některé pro určité typy textů shodné znaky $\mathrm{v}$ rovině makrostruktury i mikrostruktury, jež lze vysvětlit působením transferu, přičemž pozornost je zaměřena na interlingvní transfer pozitivní (proaktivní) v jeho dvoj- a vícesměrném působení. Jednalo se o následující typy textu: pozvánka $\mathrm{v}$ tradiční dopisové podobě a ve formě e-mailu, vzkaz (stručná zpráva), popis postupu a vyprávění obrázkového príiběhu. Tyto typy textů byly zvoleny na základě (1) předem provedené analýzy učebnic češtiny, angličtiny a němčiny, která doložila, že jsou v nich hojně zastoupeny a (2) rozhovorů s vyučujícími jednotlivých jazyků, kteří sdělili, že do své výuce nácvik těchto textů zařazují. Textový korpus obsahoval 939 textů psaných ve třech jazycích (čeština, angličtina, němčina: tedy např. pozvánka ve třech jazykových mutacích). Použita byla metoda textově lingvistické analýzy. Výzkum se zabýval problematikou transferu $\mathrm{v}$ rovině znalostí o jazyce, konkrétně v oblasti znalostí o charakteristických znacích různých typů textů. Zkoumány a srovnávány byly prezence a pragmatická instrumentalizace určitých jazykových prostředků a struktur typických pro daný typ textu ve všech třech jazycích. Na základě takto definovaných výzkumných cílù a předmětu výzkumu bylo použito pojmosloví deklarativni a procedurální znalosti (Neuner/Hufeisen/ Kursiša/ Marx/ Koithan/ Erlenwein, 2009: 24), což koresponduje $\mathrm{s}$ terminologií Společného evropského referenčního rámce pro jazyky (SERRJ), který je vymezuje následně: „Dovednosti a procedurální znalosti [...] se zakládají více na schopnostech/dovednostech, činnostech a procesech, než na deklarativních znalostech, ačkoliv takové schopnosti mohou být rozvíjeny pomocí osvojení si znalostí deklarativních.“ (SERRJ, 2002: 12). Portmann (1991: 41) vychází z Andersonovy kategorizace a rozlišuje tři základní rozdíly mezi deklarativními a procedurálními znalostmi:

${ }^{1}$ Jedním z hlavních pragmatických důvodů pro etablování se angličtiny jako prvního cizího jazyka ve vzdělávacích systémech většiny evropských zemí je, že tento jazyk v posledních desetiletích přejal roli „funkčního“ dorozumívacího prostředku (tzv. lingua franca) (Neuner, 2003: 4). 
1. „Deklarativní znalosti jedinec má nebo nemá. Procedurální znalosti vykazují rozdílnou úroveň, jedinec může mít rozvinutou určitou schopnost v určité míře.

2. Deklarativní znalosti mohou být osvojeny jednorázově, procedurální postupně.

3. Deklarativní znalosti lze poměrně snadno „sdělit“, procedurální znalosti je zpravidla velmi obtížné verbalizovat a nelze je zprostředkovat ve formě informace."

Portman (1991: 49) dále zdůrazňuje, že rozvoj určité dovednosti se opírá o deklarativní bázi. Znamená to, že se ve výzkumu odráží vícedimenzionální znalostní struktura, kdy si tvorba textů vyžaduje deklarativní znalosti v oblasti charakteristik typů, popřr. druhů textů (např. V dopise musím uvést oslovení. Musím napsat úvod.), což však ještě nemusí nutně znamenat, že jsou v konkrétním textu (adekvátně) použity. Výsledky analýzy je tak třeba interpretovat $\mathrm{s}$ ohledem na fakt, že realizace jednotlivých charakteristik typických pro daný druh textu (procedurální znalosti) může být značně odlišná od znalostní báze (deklarativní znalosti). V úvahu byly vzaty rovněž různé úrovně jazykových znalostí ve všech třech jazycích v jejich konstelaci a pořadí, v němž byly osvojovány: čeština-angličtina-němčina (Sorger, 2013: 90).

V přístupu ke zkoumané problematice bylo navázáno na dosavadní poznatky výzkumu mnohojazyčnosti v dané oblasti. Byly přitom reflektovány jeho limity, k nimž patří zejména empirickým výzkumem podložený fakt, že pozitivní transfer lze obtížněji prokázat, než transfer negativní. Na tento jev upozorňuje mj. i Böttgerová, která na základě svých výzkumů konstatuje, že , pozitivní transfer se v cílovém jazyce neprojevuje žádným zvláštním způsobem a nelze jej proto dokázat tak snadno, jak tomu je u transferu negativního. Pozitivní transfer způsobuje, že jedinec má při osvojování určitých struktur méně obtíží, než při osvojování struktur jiných. Konkrétně to znamená, že žáci si mohou osvojit některou strukturu jazyka rychleji než jinou a při jejím používání se dopouštět méně chyb (Böttger, 2008: 58). Deklarativní a procedurální znalosti korespondují s deklarativní a procedurální bází transferu. Dalším limitem byl i fakt, že při použití metody textově lingvistické analýzy lze obtížně získat spolehlivá data ohledně směru transferu. Základním východiskem byl předpoklad, že nejrozvinutější deklarativní i procedurální znalosti o makrostruktuře i mikrostruktuře analyzovaných textů mají respondenti v češtině jako mateřském jazyce, které budou transferovány do jazyků dalších. Výsledky mj. ukázaly, že (1) v jazykové výuce je v nedostatečné míře rozvíjena schopnost žáků napsat jazykově i pragmaticky správný text; (2) žáci mají mnohdy rozvinutější povědomí o struktuře textu v cizím jazyce než v češtině, což se stává pro efektivní využívání pozitivního transferu na ose $\mathrm{L} 1 \rightarrow \mathrm{L} 2 \rightarrow \mathrm{L} 3$ problematickým bodem při hledání odpovědi na hlavní výzkumné otázky týkající se zjištování vlivu mateřského jazyka na první a druhý cizí jazyk v oblasti psaného projevu. Nicméně i přes tato méně uspokojivá zjištění výsledky ukázaly, že $\mathrm{v}$ převážné většině při vytváření textů ve více jazycích u žáků k pozitivnímu transferu dochází, a to jak v jeho deklarativní (znalosti jazyka), tak i procedurální (strategie při psaní textů) rovině. Analýza textů jednoznačně prokázala poměrně velké individuální rozdíly mezi jednotlivými žáky v produkci psaných textů ve všech třech jazycích. Získané poznatky poté umožnily formulovat podněty pro jazykovou výuku, př́ípravu budoucích učitelů jazyků, jejich další vzdělávání i pro výzkum mnohojazyčnosti v rámci procesů učení a vyučování více jazykům.

\section{Závěr}

Zájem řady vědních disciplín o hlubší poznání procesů učení se mateřskému i cizím jazykům se v posledních desetiletích zintenzivňuje, což je mj. ovlivněno zvýšenými požadavky současné společnosti na rozvoj individuální mnohojazyčnosti jedince, která úzce souvisí s razantně se rozvíjející mobilitou, v jejímž rámci dochází ke stále těsnějšímu setkávání různých jazyků a kultur téměř ve všech oblastech lidské 
činnosti. Výzkum učení a vyučování (cizích) jazyků se těchto nových výzev chopil s velkým nasazením, jehož výsledkem je dynymický rozvoj empirického bádání zaměřeného na nová výzkumná témata, která se objevují v rámci multidimenzionálního konceptu mnohojazyčnosti, a to $\mathrm{v}$ jeho různých pojetích: od jeho chápání jako oborově didaktického přístupu v cizojazyčné výuce až po př́ístupy opírající se o teorie osvojování jazyků. Výzkumné pole mnohojazyčnosti je tak velmi rozrůzněné, nicméně $v$ něm lze nalézt a pojmenovat kategorie, pro něž jsou charakteristická cílená směřování a tendence včetně výzkumných přístupů a metod, a to i v oblasti explicitně se zabývající zkoumáním procesů paralelního intencionálního učení se více jazykům v jejich nejrůznější konstelaci. V současnosti se k aktuálním tématům řadí zejména zkoumání pozitivního transferu mezi jazyky s ohledem na rozvoj produkce psaného textu ve více jazycích.

\section{References}

ABENDROTH-TIMMER,D. - BREIDBACH, S. (eds.). 2000. Handlungsorientierung und Mehrsprachigkeit. Fremd- und mehrsprachliches Handeln in interkulturellen Kontexten. Frankfurt am Main: Peter Lang. ISBN 3-631-37650-2

ANDROUTSOPOULOS, J. K. 2006. Mehrsprachigkeit im deutschen Internet: Sprachwahl und Sprachwechsel in Ethno-Portalen. In: Von *hdl* bis *cul8r*. Sprache und Kommunikation in den neuen Medien, pp. 172-196. Mannheim: Dudenverlag. ISBN 3-411-04212-5

APELTAUER, E. 2001. Bilingualismus - Mehrsprachigkeit. In: Deutsch als Fremdsprache. Ein internationales Handbuch. Berlin - New York: de Gruyter, pp. 628- 637. ISBN 3-11-016940-1

ARONIN, L. - Ó LAOIRE, M. 2001. Exploring multilingualism in cultural contexts: Towards a notion of multilinguality. In: Proceedings of the Third International Conference on Third Language Acqusition. Leeuwarden, NL. CD-ROM. ISBN 978-3540-30202-5

BÄR, M. 2009. Förderung von Mehrsprachigkeit und Lernkompetenz. Tübingen: Narr Verlag. ISBN 978-3-8233-5616-5

BOCK, B. - DUMONT, B. - GROß, N. (eds.). 2006. Sprachbiographien. Interviews und Analysen. Leipzig: Universität Leipzig Pressestelle. ISBN 3-934178-60-X

BÖTTGER, K. 2008. Negativer Transfer bei russischsprachigen Deutschlernern. Dissertation, Universität Hamburg. [online] (cit. 14.15.2014) <http://ediss.sub. unihamburg.de/volltexte/2008/3622/pdf/Boettger.pdf>.

BURWITZ-MELZER, E. 2003. Allmähliche Annährungen: Fiktionale Texte im interkulturellen Fremdsprachenunterricht der Sekundarstufe I. Tübingen: Narr Verlag. ISBN 3-8252-8275-9.

CAESAR, F. 2009. Sprachbiographien und Spracherwerbsprozess. [online] (cit. 20.6.2014) <http://www.hausarbeiten. de/faecher/vorschau/212322.html>.

CENOZ, J. - HUFEISEN, B. - JESSNER, U. (eds.). 2003. The Multilingual Lexicon. Dordrecht, Netherlands: Kluwer Academic Publishers. ISBN 1-4020-1543-7

CAVALLINI, E. 2010. Deutsch nach Englisch bei Italienisch als Ausgangssprache. Eine empirische Analyse zum Tertiärspracherwerb. München: Martin Meidenbauer. ISBN 978-3-89975-198-7

CENOZ, J. - GORTER, D. 2011. Focus on Multilingualism: A Study of Trilingual Writing. In: The Modern Language Journal, vol. 95, pp. 356-369. ISSN 1540-4781

De ANGELIS, G. - JESSNER, U. 2012. Writing across languages in a bilingual context: A Dynamic Systems Theory approach. In: L2 Writing Development: Multiple Perspectives. Boston und Berlin: de Gruyter, pp. 47-68. ISBN 978-19-3407829-7

DECKE-CORNILL, H. - KÖSTER, L. 2010. Third or Additional Language Acquisition. Clevedon: Multilingual Matters. ISBN 978-1-8535-5914-5 
DENTLER, S. 2000. Deutsch und Englisch - das gibt immer Krieg! In: Tertiär- und Drittsprachen: Projekte und empirische Untersuchungen. Tübingen: Stauffenburg, pp. 77-97. ISBN 3-86057-861-8

DENTLER, S. 1998. Zur Systematizität und Prognostizierbarkeit lexikalischer Interferenzen. In: Tertiärsprachen. Theorien, Modelle, Methoden. Tübingen: Stauffenburg, pp. 31-46. ISBN 3-86057-707-7

FRANCESCHINI, R. - MIECZNIKOWSKI, J. 2004. Wie bin ich zu meinen verschiedenen Sprachen gekommen? In: Leben mit mehreren Sprachen/ Vivre avec plusiers language. Sprachbiographien. Biographies Langagiéres. Bern: Peter Lang, pp. VII-XXI. ISBN 978-3-03910-340-9

FRANCESCHINI, R. 2001. Sprachbiographien randständiger Sprecher. In: Biographie und Interkulturalität: Diskurs und Lebenspraxis. Tübingen, Stauffenburg, pp. 111-125. ISBN 3-8607-044-7

GROSEVA, M. 1998. Dient das L2-System als ein Fremdsprachenlernmodell? In: Tertiärsprachen. Theorien, Modelle, Methoden. Tübingen: Stauffenburg, pp. 21-30. ISBN 3-86057-707-7

GÜNTHER, B. - GÜNTHER, H. 2007. Erstsprache - Zweistsprache - Fremdsprache. 2. Auflage. Weinheim und Basel, Beltz Verlag. ISBN 978-3-40725-474-0

HAMMARBERG, B. 2001. Roles of L1 and L2 in L3 production and acquisition. In: Cross-Linguistic Influence in Third Language Acquisition. Psycholinguistic Perspectives. Clevedon et al.: Multilingual Matters, pp. 21-41. ISBN 978-1-85359549-3

HERDINA P. - JESSNER, U. 2002. A Dynamic Model of Multilingualism. Clevedon: Multilingual Matters. ISBN 1-85359-468-7

HORVATIC-CAJKO, I. 2013. Wie spiegeln sich sprachliche Vorkenntnisse in der L3 Deutsch im Bereich der Schreibfertigkeit wider? In: Schreiben in mehreren Sprachen. Deutsch nach Englisch: Mehrsprachigkeit und ihr Einfluss auf die Textkompetenz. Brno: Tribun EU, pp. 52-67. ISBN 978-80-263-0558-3

HU, A. 2003. Schulischer Fremdsprachenunterricht und migrationsbedingte Mehrsprachigkeit. Tübingen: Narr Verlag. ISBN 3-8233-6015-9

HUFEISEN, B. 1993. Fehleranalyse: Englisch als L2 und Deutsch als L3. [Error analysis: English as a 2nd and German as a 3rd foreign language]. In: International Review of Applied Linguistics, vol. 31, n. 3, pp. 242-256. ISSN 1613-4141

HUFEISEN, B. 2003. L1, L2, L3, L4, Lx - alle gleich? Linguistische, lernerinterne und lernerexterne Faktoren in Modellen zum multiplen Spracherwerb. In: Zeitschrift für Interkulturellen Fremdsprachenunterricht, vol. 8, n.2/3, pp. 1-13. ISSN 1205-6545

HUFEISEN, B. 2004. Deutsch und die anderen (Fremd)Sprachen im Kopf der Lernenden. Wie man dieses Potenzial im Deutschunterricht nutzen kann. In: Fremdsprache Deutsch vol. 31, n. 1, pp. 19-23. ISSN 0937-3160

HUFEISEN, B. - MARX, N. 2001. Linguistische Grundlagen und methodischdidaktische Konzeption. Linguistische Grundlagen für den Tertiärsprachenuterricht. Beispiel Deutsch nach Englisch. In: Tertiärsprachen lehren und lernen. Beispiel. Deutsch nach Englisch. (not printed)

HUFEISEN, B. - NEUNER, G. (eds.). 2005. Mehrsprachigkeitskonzept Tertiärsprachenlernen - Deutsch nach Englisch. Strasbourg: Council of Europe Publishing. ISBN 92-871-5146-6

JANIK, M. 2012. Koncept mnohojazycnosti ve vyzkumu a jeho didakticke ztvarnení. In: Aktualni temata vyzkumu uceni a vyucovani cizim jazykum. Brno: Masarykova univerzita, pp. 169-181. ISBN 978-80-210-5718-0

JANIKOVÁ, V. 2013a. Motivation und Lernen des Deutschen als zweite Fremdsprache: Teilergebnisse einer Pilotstudie. In: Deutsch als Sprache der 
(Geistes)Wissenschaften. Didaktik-Deutsch als Fremdsprache. Brno: Tribun, pp. 7785. ISBN 978-80-263-0558-3

JANIKOVÁ, V. 2013b. Mnohojazyčnost a didaktika cizích jazyků. Brno: Masarykova univerzita. ISBN 978-80-210-6683-0

JANIKOVÁ, V. 2014. Individuální mnohojazyčnost a její psycholingvistické aspekty se zřetelem k osvojování jazyků. In: XLinguae, vol. 7, n. 1, pp. 29-45. ISSN 13378384

JASPERT, K. - LEMMENS, G. 1990. Linguistic evaluation of Dutch as a third language. In: Bicultural and trilingual education. Clevedon: Avon, pp. 30-56. ISBN 185359-043-6

JESSNER, U. 1997. Towards a dynamic view of multilinguismus. In: Language Choices: Conditions, Constraints and Consequences. Amsterdam: Benjamins, pp. 1730. ISBN 978-9-0272-1831-5

KÄRCHNER-OBER, R. 2009. The German Language is Completely Different from the English Language. Gründe für die Schwierigkeiten des Lernens von Deutsch als Tertiärsprache nach Englisch bei malaysischen Studenten mit verschiedenen nichtIndo-Europäischen Erstsprachen. Eine datenbasierte, sozio-etnographische Studie. Tübingen: Narr Verlag. ISBN 978-3-86057-868-1

KJÄR, U. 2000. Deutsch als L3. Zur Interimsprache schwedischer Deutschlerner (unter Berücksichtigung des Einflusses des Englischen als L2). In: Tertiär- und Drittsprachen: Projekte und empirische Untersuchungen. Tübingen: Stauffenburg, pp. 41-55. ISBN 978-3-86057-861-2

KEMMETER, L. 1999. Multilingual gestütztes Vokabellernen im Gymnasialen Englischuntericht. Frankfurt am Main: Peter Lang Verlag. ISBN 93-872-50-46

KNAPP-POTTHOFF, A. 1997. Interkulturelle Kommunikationsfähigkeit als Lernziel. In: Aspekte interkultureller Kommunikationsfähigkeit. München: Iudicium, pp. 181205. ISBN 978-3-89129-662-2

KOBAYASHI, H. - RINNERT, C. 2013. L1/L2/L3 writing development: Longitudinal case study of a Japanese multicompetent writer. In: Journal of Second Language Writing, vol. 22, n. 1, pp. 4-33. ISSN 1060-3743

LINDEMANN, B. 2007. Motiviert für Deutsch? Eine qualitative Studie zum Anfängerunterricht $\mathrm{DaF}$ in Norwegen. Zeitschrift für Interkulturellen Fremdsprachenunterricht, vol. 12, n. 1, pp. 1-16. ISSN 1205-6545 [online] (cit. 15.3.2014) <http://zif.spz.tu-darmstadt.de/jg-12-1/beitrag/Lindemann1.htm>.

LUCHTENBERG, S. 2002. Mehrsprachigkeit und Deutschunterricht: Widerspruch oder Chance? Zu den Möglichkeiten von Language Awareness in interkultureller Deutschdidaktik. In: ide, vol. 27, n. 3, pp. 27-46. ISSN 0721-9954

MARX, N. 2004. Forschungsmethoden zur Mehrsprachigkeit und zum multiplen Spracherwerb. In: Beim Schwedischlernen sind Englisch und Deutsch ganz hilfsvoll". Untersuchungen zum multiplen Sprachenlernen. Frankfurt am Main: Peter Lang, pp. 65-79. ISBN 3-631-53021-8

MARX, N. - HUFEISEN, B. 2010. Mehrsprachigkeitskonzepte. In: Deutsch als Fremd- und Zweitsprache. Berlin - New York: De Gruyter, pp. 825-831. ISBN 978-311-020507-7

MÄGISTE, E. 1984. Learning a third language. In: Journal of Multilingual and Multicultural Development, vol. 5, n. 5, pp. 415-421. ISSN 0143-4632

McLAUGHLIN, B. 1987. Theories of Second-Language Learning. London: Edward Harold. ISBN 0-7131-6513-8

MEIßNER, F. - REINFRIED, M. (eds.). 1998. Mehrsprachigkeitsdidaktik. Konzepte, Analysen, Lehrerfahrungen mit romanischen Fremdsprachen. Tübingen: Narr. ISBN 3-631-49456-4 
MENG, K. 2001. Russlanddeutsche Sprachbiographien. Untersuchungen zur sprachlichen Integration von Aussiedlerfamilien. Tübingen: Narr Verlag. ISBN 38233-5130-3.

MERTENS, J. 2001. Die sogenannten faux amis in schriftlichen Textproduktionen von Lernern des Französischen der Sekundarstufe I. Frankfurt: Peter Lang. ISBN 97890-272-0724-1

MIßLER, B. 1999. Fremdsprachenlernerfahrungen und Lernstrategien. Eine empirische Untersuchung. Tübingen: Stauffenburg. ISBN 3-86057-862-6

MÜLLER, N. - KUPISCH, T. - SCHMITZ, K. - CANTONE, K. 2011. Einführung in die Mehrsprachigkeitsforschung. Tübingen: Narr Verlag. ISBN 3-823-36173-2

NELDE, P. H. 2003. Mehrsprachigkeit und Schulmodelle. In: Mehrsprachigkeit und Migration. Frankfurt am Main: Peter Lang, pp. 201-210. ISBN 978-3-631-50285-3

NEUNER, G. 2003. Mehrsprachigkeitskonzept und Tertiärdidaktik. In: Mehrsprachigkeitskonzept - Tertiärsprachen - Deutsch nach Englisch. Strasbourgh: Concil of Europe Publishing, s. 13-34. ISBN 92-871-5146-6

NEUNER, G. 1996. Deutsch als zweite Fremdsprache nach Englisch. Überlegungen zur Didaktik und Methodik und zur Lehrmaterialentwicklung für die „Drittsprache Deutsch“. In: Deutsch als Fremdsprache, vol. 33, n. 4, pp. 211-217. ISSN 0323-3766

NEUNER, G. - HUFEISEN, B. - KURSIŚA, A. - MARX, N. - KOITHAN, U. ERLENWEIN, S. (eds.). 2009. Deutsch als zweite Fremdsprache. Fernstudieneinheit 26. München: Goethe-Institut. ISBN 3-468-49678-8

OOMEN-WELKE, I. 1998. Kultur der Mehrsprachigkeit im Deutschunterricht. In: Wege zur Kultur. Perspektiven für einen integrativen Deutschunterricht. Frankfurt am Main: Peter Lang, pp. 289-305. ISBN 978-3-631-32675-6

PILYPAITYTÉ, L. 2013. Schreiben in der Peripherie der Tertiärsprachenforschung und -didaktik. In: Schreiben in mehreren Sprachen. Deutsch nach Englisch Mehrsprachigkeit und ihr Einfluss auf die Textkompetenz. Brno: Tribun, pp. 23-37. ISBN 978-80-263-0558-3

PORTMANN, P. R. 1991. Schreiben und Lernen. Tübingen: Max Niemeyer. ISBN 3 484-31122-3

RAMPILLON, U. 2003. Lernstrategisches Minimalprofil an der Schwelle von L2 zu L3. In: Mehrsprachigkeitskonzept - Tertärsprachen - Deutsch nach Englisch. Strasbourg: Council of Europe Publishing, pp. 85-104. ISBN 2-88198-013-9

RAUPACH, M. 1994. Das mehrsprachige Lexikon. In: Kognitive Linguistik und Fremdsprachenerwerb. Das mentale Lexikon. Tübingen: Narr Verlag, pp. 19-37. ISBN 3-8233-5040-4

REHBEIN, J. 2001. Das Konzept der Diskursanalyse. In: Text- und Gesprächslinguistik: Ein internationales Handbuch zeitgenössischer Forschung. Bd. 2. Berlin - New York: de Gruyter, pp. 927-945. ISBN 3-11-016918-5

RIEHL. C. 2004. Sprachkontaktforschung. Eine Einführung. Tübingen: Narr Verlag. ISBN 978-3-8233-6013-1

SLADKOVSKA, K. 2010. Dalsi cizi jazyk v ceskych skolach. [online] (cit. 20.2.2014) <http://clanky.rvp.cz/clanek/c/JO/9557/DALSI-CIZI-JAZYK-V-CESKYCH-

ZAKLADNICH-SKOLACH.html/>.

SELTING, M. et al. 2009. Gesprächsanalytisches Transkriptionssystem 2 (GAT 2). In: Gesprächsforschung, vol. 10, pp. 353-402. ISSN 1617-1837

SOLMECKE, G. 1993. Motivation und Motivieren im Fremdsprachenunterricht. Paderborn: Schöningh. ISBN 978-3-638-38942-6

SORGER, B. 2013. Forschungsdesign und Teilaspekte der Untersuchung. . In: Schreiben in mehreren Sprachen. Deutsch nach Englisch Mehrsprachigkeit und ihr Einfluss auf die Textkompetenz. Brno: Tribun, pp. 87-106. ISBN 978-80-263-0558-3 
SORGER, B. - KÁŇA, T. - JANÍKOVÁ, V. - REITBRECHT, S. - BRYCHOVÁ, A. (eds.). 2013. Schreiben in mehreren Sprachen. Deutsch nach Englisch: Mehrsprachigkeit und ihr Einfluss auf die Textkompetenz. Brno: Tribun. ISBN 97880-263-0558-3

SPIROPOULOU, P. P. 2000. Fehler im Tretiärsprachenunterricht. Beitrag im Rahmen eines Forschungsstipendiums am Europäischen Fremdsprachenzentrum (EFSZ) im Rahmen des Projekts "Mehrsprachigkeitskonzept - Tertiärsprachenlernen - Deutsch nach Englisch. [online] (cit. 23.2.2014) <http://www.ecml.at/documents/relresearch/ Spiroplou.pdf $>$.

STEDJE, A. 1976. Interferenz von Mutersprache und Zweitsprache auf eine dritte Sprache beim freien Sprechen: Ein Vergleich. In: Zielsprache Deutsch, vol. 7, n. 1, pp. 15-21. ISSN 0341-5864

SWAIN, M. - LAPKIN, S. - ROWEN, N. et al. 1990. The role of the mother tongue literacy in third language learning. In: Language Culture and Curriculum, vol. 3, n. 1, pp. 65-81. ISSN 0790-8318

TARGONSKA, J. 2004. Zur Nutzung der Englischkenntnisse beim Erwerb des deutschen Wortschatzes. Eine empirische Untersuchung bei polnischen Schülern. In: Beim Schwedischlernen sind Englisch und Deutsch ganz hilfsvoll. Untersuchungen zum multiplen Sprachenlernen. Frankfurt am Main: Peter Lang, pp. 117-136. ISBN 3631-53021-8

THOMAS, J. 1985. The role played by prior linguistic experience in second and third language learning. In: The Eleventh Linguistic Association of Canada and United States Forum 1984. Columbia: South Carolina, Hornbeam Press, pp. 510-518. ISBN 0-917496-25-6

TOPHINKE, D. 2002. Lebensgeschichte und Sprache. Zum Konzept der Sprachbiographie aus linguistischer Sicht. In: Bulletin VALS-ASLA, n. 76, pp. 1-14. ISSN 1023-2044

VOGEL, T. 1992. Englisch und Deutsch gibt es immer Krieg: Sprachverarbeitungsprozesse beim Erweb des Deutschen als Drittsprache. In: Zielsprache Deutsch, vol. 23, n. 2, pp. 95-99. ISSN 0341-5864

WIDDOWSON, H. G. 2007. Discourse analysis. Oxford: Oxford University Press. ISBN 978-0-19-438921-1

WOLFF, D. (ed.) 2006. Mehrsprachige Individuen - vielsprachige Gesellschaften. Frankfurt am Main: Peter Lang. ISBN 978-3-19-176100-4

Words: 8580

Characters: 62948 (34, 97 standard pages)

Prof. PhDr. Věra Janíková, PhD

Department od German Language and Literature

Faculty of Education

Masaryk University

Porriči 9

60300 Brno

Czech Republic

janikova@ped.muni.cz. 